\title{
Protection and Recycling of Architectural Heritage in Macau's Urban Renewal
}

\author{
Lier $\mathrm{Mi}^{1{ }^{1}}{ }^{*}$
}

\author{
${ }^{1}$ City University of Macau, Macau, China \\ *Corresponding author. Email: 913591779@qq.com
}

\begin{abstract}
The era of rapid urban development requires effective protection and reuse of urban architectural heritage. Urban renewal aims to replace the decaying physical space with new urban functions, while respecting and protecting the architectural heritage. In the stage of rapid urban development in Macau, architecture, as a good cultural carrier, carries a collective memory. In the early stage of urban development, Macau has paid attention to the protection of architectural heritage and established a classification protection system through a series of practical explorations. This paper takes the practice of protection and reuse of architectural heritage in Macau as the research object and discusses how to effectively use and protect architectural heritage, so as to provide reference materials for the study of architectural heritage protection in Macau and promote the effective protection and utilization of architectural heritage in the context of urban renewal.
\end{abstract}

Keywords: Macau, architectural heritage, urban renewal, classification protection mechanism

\section{INTRODUCTION}

\section{A. Research background}

The rapid urban development witnessed many urban renewal projects in full swing. However, the traditional means of comprehensive renewal have seriously damaged the urban heritage, especially leading to the reduction of space and historic buildings in historical areas. Rapid urban renewal, especially the lack of recognition of the authenticity and value of heritage, will cause new damage to heritage, which urgently needs effective protection and reuse of urban heritage. Architecture is the carrier of history and culture, so relevant personnel should analyze and comb the advantages and disadvantages between urban renewal and architectural heritage protection from a broader and deeper perspective.

\section{B. Research content}

Since 1953, the Macau government began to pay attention to the protection of urban architectural heritage, especially after the success of Macau's application for the list of world heritage in 2005, it has been further exploring the protection of architectural heritage. This paper takes the protection of architectural heritage in Macau as the research object, including the laws and regulations of architectural heritage protection, the restoration process of architectural heritage protection, public participation in architectural heritage protection and so on. The author also explores the management and practice of architectural heritage protection in Macau and analyzes the driving force of sustainable development brought to the city by the protection and comprehensive utilization of architectural heritage in Macau.

\section{Research purposes}

Most of the existing literatures focus on the form, characteristics and value of Macau architecture, while few focus on how to protect and reuse Macau architecture in the context of urban renewal. Therefore, this paper studies the protection and reuse of architectural heritage in Macau's historic urban area and puts forward the inheritance and protection of architectural heritage value in the community, hoping to bring some enlightenment to the protection of architectural heritage in other cities.

\section{OVERVIEW OF MACAU'S ARCHITECTURAL HERITAGE}

\section{A. Historical background of Macau's architectural heritage}

After more than 400 years of historical changes, Macau has changed from a fishing village on the peninsula to a world heritage city and a tourist city, and the urban space has changed accordingly. Macau's culture is composed of Chinese culture and Portuguese culture, with different ethnic groups and cultural backgrounds, creating a rich variety of architectural types in Macau. At the very beginning, most Portuguese colonial buildings were mainly European church buildings, which are the oldest extant western architectural heritage in China and the comprehensive embodiment of eastern and western architectural art. In this compact urban space, the Chinese and European cultures are embodied through the vehicle of architecture, embracing each other and remaining independent. Thus it can be seen that Macau is the earliest place in China to contact with modern western artifacts and culture, and also the first stop for modern western 
architecture to be introduced into China (Chen Zecheng, 2009).

\section{B. Status quo of architectural heritage in Macau}

As for the overall value of Macau's architectural heritage, it was influenced by the architectural styles of Portuguese colonial areas before the handover, so a variety of architectural heritages intermingled in Macau. Macau has 22 buildings listed on the world cultural heritage list. Temples and houses of intellectuals with a unique Lingnan architectural design and European churches, theatres, cemeteries, etc. are strung together like a necklace from south to north. (See "Table I")

TABLE I. ANALYSIS ON MACAU'S ARCHITECTURAL HERITAGE

\begin{tabular}{|c|c|c|c|c|}
\hline Building & Construction time & $\begin{array}{c}\text { Building } \\
\text { restrictions }\end{array}$ & Types & Continuity of the building \\
\hline A-Ma Temple & $\begin{array}{l}1605 \text { (33rd years } \\
\text { of Wanli of the } \\
\text { Ming Dynasty) }\end{array}$ & memorial & Religious building & $\begin{array}{l}\text { It is the oldest temple in Macau. After a } \\
\text { fire in 1988, the Macau government } \\
\text { restored it to its original appearance. }\end{array}$ \\
\hline $\begin{array}{l}\text { Moorish } \\
\text { Barracks }\end{array}$ & 1874 & $\begin{array}{l}\text { It has architectural } \\
\text { artistic value. }\end{array}$ & $\begin{array}{l}\text { Modern military } \\
\text { architecture }\end{array}$ & $\begin{array}{l}\text { In } 1905 \text {, the building was converted } \\
\text { into port office and Polcia Martima e } \\
\text { Fiscal It is now the office building of } \\
\text { port office. }\end{array}$ \\
\hline $\begin{array}{l}\text { Mandarin's house } \\
\text { in Macau }\end{array}$ & $\begin{array}{l}1881 \text { (the seventh } \\
\text { year of the reign of } \\
\text { Emperor Guangxu) }\end{array}$ & $\begin{array}{l}\text { It has architectural } \\
\text { artistic value. }\end{array}$ & $\begin{array}{l}\text { Modern residential } \\
\text { architecture }\end{array}$ & $\begin{array}{l}\text { The government restored it to its } \\
\text { original condition in } 2001 \text {. }\end{array}$ \\
\hline $\begin{array}{l}\text { Igreja de So } \\
\text { Loureno }\end{array}$ & about 1569 & memorial & Religious building & $\begin{array}{l}\text { Originally a wooden church, it was } \\
\text { rebuilt in } 1844 \text { to its present size. The } \\
\text { government paid for the repairs in } 2002 \text {. } \\
\text { The main body is brick structure. }\end{array}$ \\
\hline Teatro de Pedro & 1860 & $\begin{array}{l}\text { It has architectural } \\
\text { artistic value. }\end{array}$ & $\begin{array}{ll}\text { Modern } & \text { public } \\
\text { architecture } & \end{array}$ & $\begin{array}{l}\text { It was the first western-style theatre in } \\
\text { China and still retains its recreational } \\
\text { function. }\end{array}$ \\
\hline $\begin{array}{l}\text { Biblioteca Sir } \\
\text { Robert Ho Tung }\end{array}$ & 1894 & $\begin{array}{l}\text { It has architectural } \\
\text { artistic value. }\end{array}$ & $\begin{array}{ll}\begin{array}{l}\text { Modern } \\
\text { architecture }\end{array} & \text { public } \\
\end{array}$ & $\begin{array}{l}\text { Originally a private villa, it was opened } \\
\text { as a public library after } 1958 \text {. }\end{array}$ \\
\hline $\begin{array}{ll}\begin{array}{l}\text { St. } \\
\text { church }\end{array} & \text { Austin's } \\
\end{array}$ & 1875 & memorial & Religious building & $\begin{array}{l}\text { The church started out as a very } \\
\text { humble, manipulative building, and was } \\
\text { restored in } 1874 \text { to its present size. }\end{array}$ \\
\hline $\begin{array}{l}\text { Leal Senado } \\
\text { Building }\end{array}$ & 1784 & memorial & $\begin{array}{l}\text { Modern } \\
\text { administrative } \\
\text { architecture }\end{array}$ & $\begin{array}{l}\text { Originally a city hall, it was restored in } \\
1874 \text { to its present size, with the second } \\
\text { floor now a museum. }\end{array}$ \\
\hline Rosary Church & 1587 & memorial & Religious building & $\begin{array}{l}\text { When it was first built, most of the } \\
\text { structure was damaged by insects } \\
\text { because it was made of wood. In 1991, } \\
\text { the Macau cultural bureau restored the } \\
\text { building, and the second and third } \\
\text { floors are now museums. }\end{array}$ \\
\hline Ruins of St. Paul & 1580 & memorial & Religious building & $\begin{array}{l}\text { It was a church, but only the facade was } \\
\text { left because of the fire. }\end{array}$ \\
\hline Na Zha temple & 1898 & memorial & Religious building & $\begin{array}{l}\text { The Macau government repaired the } \\
\text { temple in } 1995 \text { and } 2000 \text {, repairing the } \\
\text { temple's permanent structure and } \\
\text { replacing the decaying wood. }\end{array}$ \\
\hline $\begin{array}{l}\text { Ruins of the old } \\
\text { city wall }\end{array}$ & 1569 & memorial & & \\
\hline
\end{tabular}




\begin{tabular}{|c|c|c|c|c|}
\hline Building & Construction time & $\begin{array}{c}\text { Building } \\
\text { restrictions }\end{array}$ & Types & Continuity of the building \\
\hline $\begin{array}{l}\text { fortaleza do } \\
\text { monte }\end{array}$ & & $\begin{array}{l}\text { It has architectural } \\
\text { artistic value. }\end{array}$ & military building & $\begin{array}{l}\text { Now it is changed to a weather station } \\
\text { and repaired in } 1996 \text {. In order to } \\
\text { maintain authenticity, it cleaned the } \\
\text { external walls and repaired with raw } \\
\text { materials. }\end{array}$ \\
\hline Casa Garden & Mid-18th century & $\begin{array}{l}\text { It has architectural } \\
\text { artistic value. }\end{array}$ & $\begin{array}{l}\text { Modern residential } \\
\text { architecture }\end{array}$ & $\begin{array}{l}\text { It used to be the first garden villa in } \\
\text { Macau and is now the meeting site of } \\
\text { Casa Garden. }\end{array}$ \\
\hline $\begin{array}{l}\text { Protestant } \\
\text { Cemetery }\end{array}$ & & memorial & Religious building & $\begin{array}{l}\text { The cemetery is divided into two parts. } \\
\text { The Morrison chapel, which was built } \\
\text { at the same time with the cemetery, is } \\
\text { the first Christian mission center in } \\
\text { Macau. It was rebuilt in 1922. The } \\
\text { restored church is modeled after the } \\
\text { Roman style architecture. }\end{array}$ \\
\hline $\begin{array}{l}\text { The Guia } \\
\text { Fortress } \\
\text { (Including the } \\
\text { Guia Fortress } \\
\text { and the holy } \\
\text { church of the } \\
\text { virgin snow hall) }\end{array}$ & 1622 & memorial & $\begin{array}{l}\text { military } \\
\text { building/religious } \\
\text { building }\end{array}$ & $\begin{array}{l}\text { In } 1996 \text {, the government protected the } \\
\text { interior of the church. }\end{array}$ \\
\hline
\end{tabular}

\section{The universal value of Macau's architectural heritage}

Over the past 400 years, as people from all over the world have settled in Macau, architectural styles of various countries have emerged in Macau. Macau became the first stop for modern western architecture to be introduced into China, especially the churches built by Portuguese in Macau, which showed a close relationship with local Portuguese architecture. Some architectural styles of the late Renaissance combined architectural elements from other parts of Asia to produce new architectural styles in Macau. Macau has long paid attention to the protection of architectural heritage and established a classification protection system through a series of practices. According to the different types of buildings combined with the actual situation of urban development in Macau, multiple protection modes are adopted.

\section{THE PRACTICE OF PROTECTION AND REUSE OF ARCHITECTURAL HERITAGE IN MACAU}

\section{A. Sound laws and regulations and strict management measures}

The effective protection of architectural heritage cannot be separated from the promotion of the government. The Macau government attaches great importance to the protection of cultural relics and heritage. Since 1953, the Portuguese and Australian government began to pay attention to the protection of cultural heritage, but the proposed law only protects some churches and palaces. Since the return of Macau to China, some traditional Chinese houses in the historic urban areas have been protected and restored. In particular, a series of related laws and regulations on the protection of architectural heritage have been promoted after the successful application of Macau's historic urban areas to the world heritage list. (See "Table II") The law gradually changed from protecting individual architectural heritages to protecting historic buildings and urban structures. Although the Macau government has introduced a series of measures on architectural protection, due to the lack of overall urban development planning, various departments cannot effectively communicate with each other, and the sustainable protection of architectural heritage cannot be achieved only by relying on the power of the Bureau of Culture. 
TABLE II. RELEVANT LAWS AND REGULATIONS ON THE PROTECTION OF MACAU'S ARCHITECTURAL HERITAGE

\begin{tabular}{|c|c|c|}
\hline Year & Laws and decrees & Laws and decrees \\
\hline 1953 & Identifying existing architectural artifacts & $\begin{array}{l}\text { For the first time in Macau, the relevant laws on urban protection work are officially } \\
\text { written. }\end{array}$ \\
\hline 1960 & $\begin{array}{l}\text { Appropriate measures should be studied and } \\
\text { proposed to preserve and attach importance } \\
\text { to historical and artistic artifacts }\end{array}$ & Only individual buildings are protected \\
\hline 1976 & decree $34 / 76 / \mathrm{M}$ & $\begin{array}{l}\text { The first comprehensive act on the protection of civilized buildings The names and groups } \\
\text { of buildings protected are specified, and the maintenance of Macau's urban landscape and } \\
\text { cultural property was established. A clear classification and definition were made for the } \\
\text { objects to be protected, and } 89 \text { items were included in the protection list. }\end{array}$ \\
\hline 1984 & decree 56/84/M & $\begin{array}{l}\text { The decree cancels the } 4 / 76 / \mathrm{M} \text { decree, carries out a comprehensive classification and } \\
\text { definition of cultural relics in Macau, and makes a detailed protection plan for different } \\
\text { types of architectural heritages. }\end{array}$ \\
\hline 2013 & decree $11 / 2013$ & decree $11 / 2013$ \\
\hline 2014 & administrative laws and regulations $4 / 2014$ & administrative laws and regulations $4 / 2014$ \\
\hline 2017 & administrative laws and regulations $1 / 2017$ & $\begin{array}{l}\text { Assessment of monuments, buildings of architectural value and establishment of buffer } \\
\text { zones. }\end{array}$ \\
\hline 2018 & administrative laws and regulations $31 / 2018$ & administrative laws and regulations $31 / 2018$ \\
\hline
\end{tabular}

\section{B. Controling the daily flow of visitors to the architectural heritage}

If a large number of tourists enter at the same time, some crowding accidents will inevitably occur, which will not only cause personal injury to tourists, but also cause irreparable damage to buildings. Macau Government Tourist Office has specified a daily limit on the number of visitors to some historic buildings. For example, at the same time, the Casa de Lou Kau can only receive up to 30 visitors. The visiting space on the second floor is only open on weekends and public holidays. A maximum of 10 visitors are allowed at any one time. Visitors must follow the guided tour.

\section{Protection mechanism of architectural heritage}

In order to better protect the historical architectural heritage, the Macau SAR government has formulated comprehensive management requirements in accordance with the heritage protection law. According to the construction restriction condition, the construction restriction condition concerning the real estate area to be evaluated should be established by the principle of protection, moderate activation and utilization.

1) Classification of architectural heritage: Before the protection of architectural heritages, the classification of architectural heritages should be carried out first, and different protection modes should be made for architectural heritages according to the requirements of different grades. Through the preliminary investigation and evaluation, the Macau government divides the architectural heritage into four grades: monuments, buildings with architectural art value, buildings and sites, which have different requirements according to different grades. (See "Table III" and "Fig. 1")

\section{TABLE III. CLASSIFICATION OF ARCHITECTURAL PROTECTION IN MACAU}

\begin{tabular}{|c|c|}
\hline Construction class & Content of building protection \\
\hline memorial & $\begin{array}{l}\text { First, the real estate must be preserved; Secondly, local restoration or optimization works may be carried out after the } \\
\text { assessment and comments of the Bureau of Culture in cases conducive to the preservation, restoration or display of the } \\
\text { monument's value. Finally, the trees in the protection list of ancient and famous trees within the scope shall be preserved, and } \\
\text { the authorities shall obtain the advice of the cultural bureau to preserve the trees within the scope as far as possible. }\end{array}$ \\
\hline $\begin{array}{l}\text { A building of artistic } \\
\text { value }\end{array}$ & $\begin{array}{l}\text { First, the real estate must be preserved; Secondly, local changes may be made internally after the assessment and opinion of } \\
\text { the cultural bureau in cases conducive to the preservation, restoration or demonstration of the value of the monument. Finally, } \\
\text { the trees in the protection list of ancient and famous trees within the scope shall be preserved, and the authorities shall obtain } \\
\text { the advice of the cultural bureau to preserve the trees within the scope as far as possible. }\end{array}$ \\
\hline building group & $\begin{array}{l}\text { First of all, in principle, all the facades along the street should be retained, but local changes can be made after assessment and } \\
\text { comments from the cultural bureau without reducing the value of the buildings. Secondly, if there is an extension, it should be } \\
\text { in harmony with the overall architectural characteristics of the complex. Finally, the trees in the protection list of ancient and } \\
\text { famous trees within the scope shall be preserved, and the authorities shall obtain the advice of the cultural bureau to preserve } \\
\text { the trees within the scope as far as possible. }\end{array}$ \\
\hline Site & $\begin{array}{l}\text { First, it is necessary to maintain or highlight the environmental characteristics of the site, such as topography, green space, } \\
\text { overall green rate, land coverage rate, land use status and other characteristics. Secondly, related to the site of the mountain, } \\
\text { the height of the building should be coordinated with the site's morphological characteristics, and the mountain mainly by the } \\
\text { contour of the surface shall not be disturbed. Thirdly, the trees in the protection list of ancient and famous trees within the } \\
\text { scope shall be preserved, and the authorities shall obtain the advice of the cultural bureau to preserve the ancient trees within } \\
\text { the scope as far as possible. Finally, any historical or characteristic structures within the area that are closely related to the site } \\
\text { should be preserved. }\end{array}$ \\
\hline
\end{tabular}


2) Construction restrictions on adjacent sections of architectural heritage: To continue the contextual relationship between the assessed memorial building and its surrounding environment, to avoid being obstructed or disturbed by the adjacent built environment, or for the consideration of the management and maintenance of the assessed real estate and the structural safety, the adjacent area to the memorial building has been defined, which must be coordinated with the memorial building in terms of height, volume, color and facade design. In this way, it can avoid the spatial oppression or impact on the landscape quality of the assessed monuments, and it can not interfere with and block the visual view of the assessed monuments from main street nodes or open space, so as to ensure their good presentation.

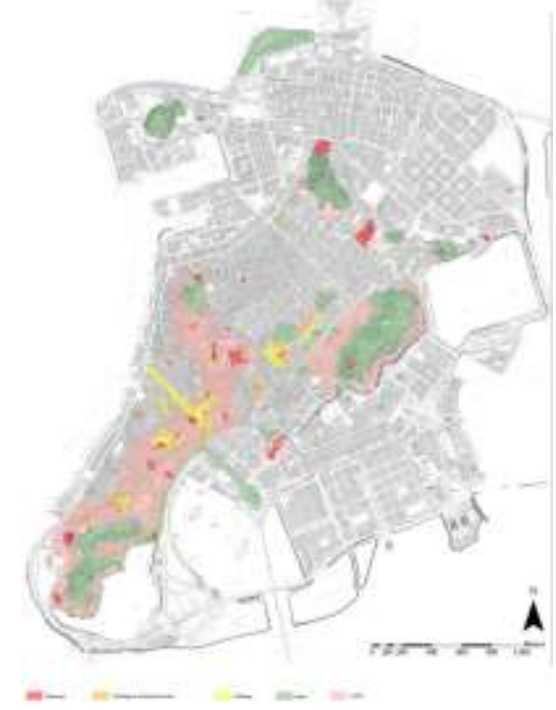

Fig. 1. The assessed real estate distribution and buffer distribution (Macau administrative code No.31/2018).

\section{Restoration of architectural heritage}

In terms of architectural restoration, the early restored buildings were mainly churches. After the return, the architectural heritage protection in Macau was mainly influenced by Portugal at that time, and the earliest architectural restoration was almost mainly restored by Portuguese architects. After the return of Macau, the architectural restoration has been continuously practiced and some international restoration concepts have been absorbed, and a relatively clear restoration concept and mature management mode have been formed. In the process of restoration, a rigorous attitude has been adopted. In the continuation of real estate features, such as the restoration of Mandarin's house in Macau, the oyster shell window is a classic component of the Lingnan building. In restoring the construction of the building, the original objects were retained or repaired according to known raw materials and techniques, rather than replacing windows of other styles to avoid disturbing or reducing the identificability of architectural features of the period. The principle of completeness and authenticity can be followed to continue the integrity of the context of architectural heritage and avoid speculative restoration. The historical textual research in the restoration process serves as the basis for the original appearance of the dialectical building. For example, in the repair of Mandarin's house in Macau, due to the defects in the gray plastic pattern on the building, the original location, form, material and technology were repaired. (See "Fig. 2") The Macau government has established the principle of minimal intervention in the restoration of buildings, taking the minimum and necessary restoration treatment as far as possible to retain the maximum historical information of buildings. For example, when repairing the Fortaleza Do Monte, only the external wall was cleaned and coated with protective paint, and the repair was carried out with raw materials. In order to ensure the continuity of architectural restoration work within a certain period of time, and to provide a scientific reference for each restoration work, the Macau cultural bureau has formulated a corresponding universal and targeted technical guide. The reasonableness principle of the procedure should be followed. There are strict working procedures for the restoration of Macau's architectural heritage to ensure the scientificity and rigor of the restoration (See "Fig. 3")

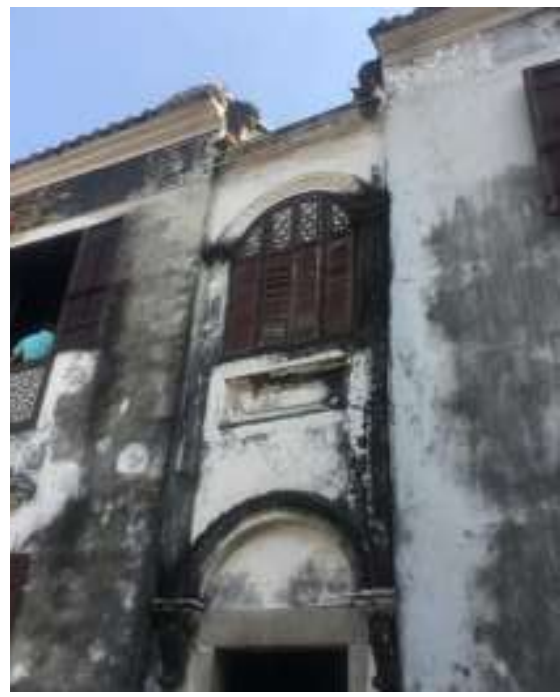

Fig. 2. The external wall of Mandarin's house in Macau (Photographed by this research). 


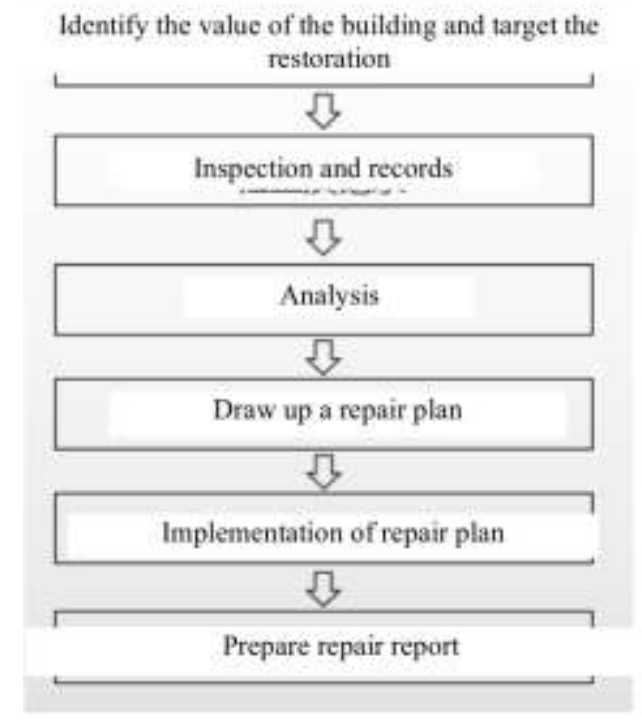

Fig. 3. Flow chart of building restoration in Macau (Drawn by the author).

\section{E. Education and promotion of architectural heritage protection among the public}

1) Public participation in the protection of architectural heritage: As an important carrier of social heritage protection, public participation and community building play a crucial role in the " $5 \mathrm{C} "$ strategy. The protection and sustainable development of architectural heritage is often inseparable from community development. Since the beginning of the 20th century, the Macau and Portuguese authorities have formed a sense of protection of Macau's indigenous architectural heritage. After the return, the protection of architectural heritage has gradually shifted to the people, who have launched many activities to protect architectural heritage. In order to arouse the public's concern for and support for the protection of architectural heritage, community rest elements are added into the protection planning according to the actual situation, which changes from centralized management to community management.

Organizations of different associations in Macau often collect public opinions on heritage protection and feedback them to the Bureau of Culture. They also launch voluntary protection plans to protect and promote Macau's architectural heritage with the approval and suggestions of the Bureau. The Macau bureau of culture certifies the effectiveness of these community activities and provides necessary technical and financial support. Some associations also hold public forums to allow the public to express their views on architectural conservation and to promote the cultural heritage of Macau and related conservation technologies and strategies. For example, in 2004, a group of young people trained in the department of cultural heritage established the Association of Macau Heritage Ambassadors and launched the "Heritage Ambassador Program" to raise awareness of architectural heritage among local residents.

2) Protection and promotion of architectural heritage and youth education: Since Macau's application for World Heritage, the Macau SAR government has made full use of different types of promotion techniques to carry out publicity and education activities through multiple channels and at multiple levels. Starting with youth education, the Macau SAR government has organized activities on architectural heritage protection so that teachers and students can walk into historical buildings. The cultural bureau of Macau organized Tours of historical buildings, and young students of Macau applied for volunteers to explain the history of the buildings, which well stimulated the awareness of young people on the protection of architectural cultural heritage. Free guided tour service will be provided to all schools in Macau in each building heritage. Students are welcome to visit or conduct teaching activities. The establishment of various social youth organizations, such as the nonprofit association of Macau ambassadors of cultural heritage, organized by local youth organizations, aims at bringing together young people who are energetic, creative and passionate about local culture to promote the education of Macau's historical heritage.

\section{F. Specimen protection to activation}

The activation of architectural heritage allows the public to no longer watch from the outside, but to enter the internal space of the building to feel the historical culture of the building. The reuse mode of Macau's architectural heritage is mainly "adaptability". After Rosary Church was restored, the first floor was still used for prayer, and the second and third floors were represented to the world in the form of a museum. (See "Fig. 4") After the restoration, the Teatro de Pedro has not only left the footprints of the Portuguese in Macau's entertainment, but also maintained its original functions, providing a distinctive venue for Macau's cultural and artistic activities. It is also one of the oldest evidence of the development of Macau's performing arts. (See "Fig. 5") After the restoration, the Lou Kau Mansion continued to introduce a variety of exciting activities, and it has become a theater stage, a flower exhibition hall, and a Chinese music hall. Famous folk craft masters from the mainland exhibited their skills and held art workshops to allow visitors and local young people to experience the history and culture of Macau. 


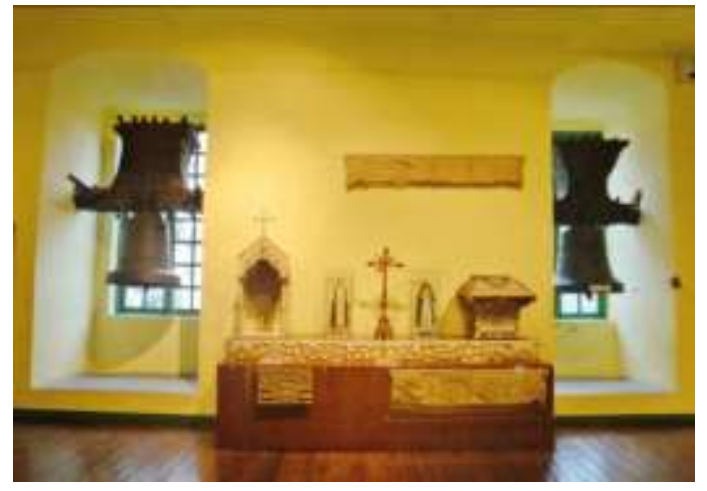

Fig. 4. The museum of Rosary (Shot by the author himself).

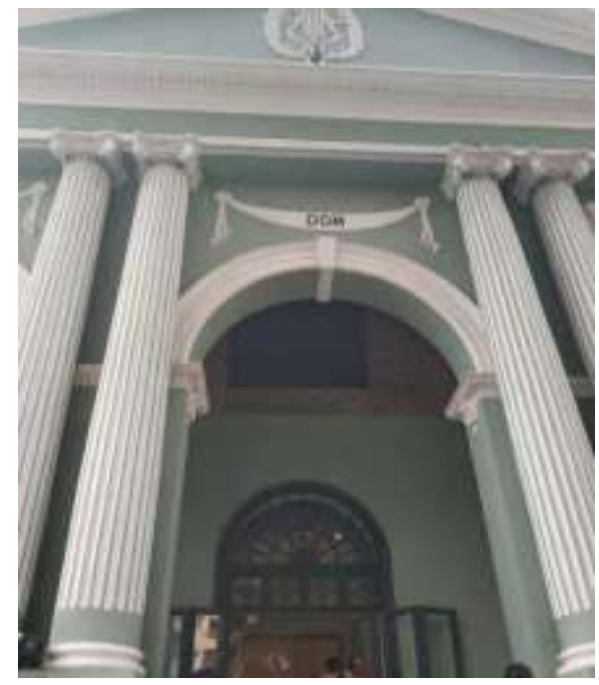

Fig. 5. Church Teatro de Pedro (Shot by the author himself).

\section{Prospect}

\section{A. Integration of traditional construction skills and modern technology}

People can make use of scientific and technological means to show the architectural heritage in front of the world, increase the application of digital technology, and use virtual reality technology and other ways to show the value of historical architectural heritage. The method of virtual digital can show the historical and cultural connotation of architecture to the world. Nowadays, the planarization digital data are mostly used in the preliminary analysis of architectural heritage protection, which leads to the idealized restoration results. The three-dimensional technology can generate understanding of the restored buildings in advance, and realize the transformation from resource digitalization to scenario-based resource. The convenient guided tour function enables people to scan the QR code with their mobile phones to learn about the historical development of the building, instead of the current situation where most tourists visit the building in the form of a cursory tour, which enables them to better understand the culture and history behind the architectural heritage. The use of light to illuminate the architectural model, on the one hand, can make people have a new understanding of architecture, on the other hand, from the perspective of urban economy, can better develop the urban night economy.

\section{B. Enhancing public participation and community building in the protection of architectural heritage}

The public's participation in the protection of architectural heritage is not only the protection of architectural heritage, but also the continuation of urban historical and cultural heritage. As the carrier of historical and cultural heritage of an era, public participation not only changes the public's attitude towards cultural heritage, but also promotes the inheritance of historical and cultural heritage. Architectural heritage provides an emotional and intellectual platform for individuals and communities to build their own identities. Citizens should have the right to review architectural heritage. Without community involvement, heritage management ignores its social consequences and undermines people's connection to architectural heritage. Policymakers should hear more voices to create more public participation opportunities in the management of architectural heritage. Therefore, community participation is crucial to the performance of architectural heritage protection. In addition, teachers and students in colleges and universities can go into the community to talk about the protection methods of architectural heritage to the community residents, so as to continuously guide the community to participate in the protection of architectural heritage and the revival of historical culture.

\section{Establishing comprehensive architectural protection}

At present, the protection of architectural heritage still focuses on the protection of independent buildings, lacking some continuous space creation and integration of historical context. The spread of point protection to surface protection, and then to the regional protection of the whole, makes each building interweave together to show the overall value of the narrative.

\section{Strengthening cooperation on regional architectural heritage conservation}

Regional resources should be integrated to further protect the architectural heritage. The historical culture of a region is often closely related, and architecture is the carrier of urban historical and cultural memory. The history of architecture can be excavated under the historical and cultural background of the region, which provides various reference materials for the protection of architecture. 


\section{E. Strengthening the cultivation of professionals dedicated to the protection of local architectural heritages}

Developing appropriate methods and techniques and finding professionals who can perform these tasks in daily practice is a huge challenge. Therefore, it is very useful to carry out professional education and training for the protectors in the field of local architectural heritage protection. Strengthening local professionals can not only deepen the recognition of the history and culture of the hometown, but also increase the pool of local talents.

\section{CONCluSion}

In the process of urban renewal, although some architectural heritages hinder the development of the region, architectural heritages, as the carrier of urban history, should be treated with a correct attitude. The great demolition and construction of cities in history will cause the original humanistic history and culture of cities to gradually die out, which will result in the phenomenon of a thousand cities, and the loss of Macau's inside information, development track and religious belief. The protection of architectural heritage is not for the sake of protection, but for the purpose of cultural inheritance. This paper studies the protection of architectural heritage in Macau, summarizes the relevant practical measures of architectural heritage protection in Macau, and hopes to provide new ideas and methods for other urban architectural heritage protection.

\section{References}

[1] Fu Xuan. Research on Modern Residential Buildings in Macau Based on the Combination of Chinese and Western [D]. Guangzhou, Huaqiao University, 2017. (in Chinese)

[2] Chen Zecheng. The Integration of Chinese and Western Cultures from the Perspective of Macau's Urban Architecture [D]. Xiamen, Xiamen University, 2009. (in Chinese)

[3] Liu Xianjue, Xu Zheng. The Religious Architecture in Macau [M]. Hua Zhong Architecture. 2002. (in Chinese)

[4] M. Shan Jixiang. Discrimination of the Development Path from "Functional City" to "Cultural City" [M]. Literature Art Studies. 2015, P41-P53. (in Chinese)

[5] Ruan Yisan, Ding Feng. Urban Heritage Protection and the Growth of Civil Power in China [M]. Construction Science and Technology. 2015, P54-P55. (in Chinese)

[6] Xu Leiqing, Wu wei, Wan Pengpeng. Research on Development Strategies of Historical Cultural Blocks in Macau: From the Perspective of Pedestrian Flow [J]. South Architecture. 2015. $\mathrm{P} 10-\mathrm{P} 15$. (in Chinese) 